Book Review

\title{
In Defence of War. By Nigel Biggar. Oxford, UK: Oxford University Press, 2013, 361 pp.; ISBN: 978-0-19-872583-1.
}

\author{
Daniel Fiott \\ Institute for European Studies, Vrije Universiteit Brussel, 1050 Brussels, Belgium; E-Mail: daniel.fiott@vub.ac.be
}

Submitted: 25 May 2015 | Accepted: 3 July 2015 | Published: 10 August 2015

\author{
Abstract \\ 872583-1.

\section{Keywords} \\ christian realism; intervention; just war; pacifism
}

Book Review: In Defence of War. By Nigel Biggar. Oxford, UK: Oxford University Press, 2013, 361 pp.; ISBN: 978-0-19-

\section{Issue}

This book review is part of a regular issue of Politics and Governance, edited by Professor Andrej J. Zwitter (University of Groningen, The Netherlands) and Professor Amelia Hadfield (Canterbury Christ Church University, UK).

(C) 2015 by the author; licensee Cogitatio (Lisbon, Portugal). This article is licensed under a Creative Commons Attribution 4.0 International License (CC BY).

There are few provocative book titles as In Defence of War, yet, misleadingly perhaps, this is not a book about the defence of war per se but the just conditions under which war may or may not be perpetrated. Nigel Biggar's monograph thus fits neatly into the canon of books on just war theory. The title In Defence of "Just" War would be nearer to Biggar's scholarly contribution. The book is divided into three main arguments. First, Biggar refutes Christian pacifism and the assumption that Christian thought and dogma (in the form of the New Testament) is necessarily pacifist. Second, he sets out, or rather restates, the criteria of the just war tradition. Finally, and most controversially, he applies these criteria to the U.S.-led intervention of Iraq in 2003 and asks whether that war was just or not: he believes it was. Each of these arguments is elegantly and astutely argued with philosophical dexterity, and, whatever is ultimately made of his arguments, this is a well argued and worthy read.

What is Biggar's departure point? First, he is keen to stress that he writes the book as theologian and not as a diplomat, soldier or political scientist (p. 331). In this vein, he draws on a range of just war theorists reaching back through Grotius to Augustine and he argues that a just war is basically a punitive response to grave injustice (p. 212). Accordingly, while Biggar acknowledges the horrors and evil that can be unleashed by war, he takes strong exception with those Christian pacifists that argue that war must be avoided at all costs. As a theologian, and based on an Augustinian reading of human nature, which recognises humanity's aptitude for both good and evil, Biggar argues that sometimes war must be fought as a way to redress injustice. Not all wars, he stresses, can be avoided and injustice must be punished (p. 10).

In this regard, one of the most compelling arguments made by Biggar is that Christian pacifists such as Stanley Hauerwas, John Howard Yoder and Richard Hays do not recognise that peace, like war, can also be a great evil if it lets injustice prevail (pp. 7, 33). Whereas Reinhold Niebuhr was critical of Christian pacifists too, although he acknowledged that they may play a role in stopping states from going to war without scruples and ethics (see p. 31 of Christianity and Power Politics), Biggar is less forgiving of his theological brethren. He almost seems to mock Hauerwas, Yoder and Hays for placing too much faith in the idea that, because Jesus seemingly rejected violence in all its forms, so must Christians.

It is on this point that Biggar engages in a debate about how one interprets the New Testament. For the secular reader this is perhaps the weakest part of the 
book. While the chapter is central to Christian debates about war and peace, and it certainly helps the reader contrast Biggar's views with those of his fellow theologians, in places the chapter reads as a superfluous exercise in hierographology. Biggar himself acknowledges that the Bible can hold many meanings and a close reading of the text will lead to different interpretations (see p. 18). It is, therefore, bemusing to see Biggar engage in this type of interpretive debate (see p. 25) when to most readers it will seem obvious that seeking guidance for matters of war and peace on the basis of a text written many centuries ago is problematic, to say the least. For those readers with a background in International Relations, it may have been more interesting to see Biggar use his opening chapter to substantially engage with the thoughts of Niebuhr, especially given that Biggar does not share all of Niebuhr's ideas (p. 11). Beyond an analysis of Moral Man and Immoral Society (1960) and An Interpretation of Christian Ethics (1979), Biggar does not engage with Niebuhr's earlier thinking as set down in Christianity and Power Politics (1940) or Christian Realism and Political Problems (1953).

Yet there are elements of this debate that should nonetheless be illuminating to the secular reader. First, Biggar does a splendid job of placing the just war tradition in its proper historical context. For example, he picks apart David Rodin's argument that the just war tradition is theoretically flawed because it is based on notions of national defence and sovereignty. This claim, Biggar contends, is only possible because Rodin looks at the just war tradition from the late modern period onwards, when, in fact, if one looks at the early modern period, one will see that the main concern for just war thinkers was injustice and not the defence of the nation-state. Biggar expertly makes his case by looking at the thoughts of a wide-range of thinkers from Aquinas through to de Vitoria and Suarez and then Grotius. Biggar shows how the just war tradition has a long history, although he could have made more of the way in which the arguments made under the tradition have altered over the course of history. Indeed, the fact that Rodin was able to reach one conclusion about the just war tradition and Biggar reaches quite another relates back to the problem of interpretation. This is not even to speak, as Richard Tuck has so excellently demonstrated, about how just war thinking even predates Christianity (see his The Rights of War and Peace: Political Thought and the International Order from Grotius to Kant (2002)).

Nevertheless, all of this should not take away from the manner in which Biggar superbly refutes Christian pacifism's claim that all war is immoral, evil and should be avoided at all costs. Once Biggar has extricated himself from the hierographical debate in chapter one, he builds a rather moving case that reaches beyond the ethical generalisations often forwarded by the Christian pacifists. He does this by looking at the real-life experiences of those who fought in wars such as the Great War and Kosovo, and Biggar's ability to bring to life the ethical experiences of soldiers in these wars is truly commendable. The chapter "Love in War" shows how soldiers and military planners deal with resentment, compassion, forgiveness, repentance, injustice, proportionality and retribution during war. Far from casting war as a completely immoral act, Biggar's nuanced interpretation of the morality of war helps us question the simplistic dichotomy of "peace = good" and "war = evil" forwarded by the Christian pacifists.

On what grounds then might one criticise Biggar's arguments? One might take exception with the rigidity that comes from thinking that just war is merely about punishing gross injustices. Biggar is at pains to say that justice is central to the perpetration of a just war, but he does not sufficiently pay attention to the historical context in which justice is framed. While it is true that Biggar recognises that war will be judged differently as history develops (p. 305), he still gives one the impression that justice is fixed through time, when, although this may or may not be the case, surely the nature of those perpetrating gross injustice colours the extent to which states are willing to fight wars. For example, Biggar makes the case that Nazism and Saddam Hussein's tyrannical regime, while different in their aims and extremes, should still answer to a fixed understanding of injustice and it is this understanding, rather than the different dangers posed by these regimes, which should condition our recourse to war. This is surely to misunderstand the motivations of states when they do decide to go to war. Nazism was a clear and present danger to the allies (bombs were being dropped on London), whereas Saddam's regime posed a different sort of danger to the world. The degree of threat is as much a part of the calculations of states, and so it is not inconceivable that this will play a role in how one decides whether war is just or not. Similarly, the potential level of destruction of any given war must fit in with our understanding of justice. The threat of mutually assured destruction would certainly play a crucial role in whether one punishes injustice or not.

Justice is necessarily bound up with such considerations. Biggar even acknowledges this when he remarks that the "legal case [for war] is bound to involve moral elements. Morality and legality are not separable" ( $p$. 248). Yet, if one accepts the implications of an international system comprised of states, notions of justice, legality and morality must also stand alongside questions of international politics and military strategy. Surely this is the reason why the US could invade Iraq, but it will not do so in North Korea? Furthermore, even if war is initially based on justice it can lead to consequences that are far from just: conducting war is not like police work. As Biggar himself acknowledges, 'once we relax the leash on the dogs of war, we should expect to be dragged where we do not want to go. Long 
experience has taught that war has a momentum of its own-partly military, partly political-that is not readily controlled' (pp. 252-253). Nevertheless, Biggar argues that because states can never truly know the consequences of unleashing the dogs of war, this should not stop them from using force to punish gross injustice. For example, with the benefit of hindsight he openly acknowledges the tragic consequences of the second Iraq war, but he still holds that the initial rationale for war of punishing Saddam and his regime for the injustices they caused was just.

Indeed, Biggar's central argument about just war hinges on the reader's acceptance of the importance of justice. This causes a rather particular problem. While Biggar is not a cosmopolitan thinker in the traditional sense-he does not, for example, believe that global government is possible (see pp. 241-242)-, his emphasis on justice has a distinctly cosmopolitan appeal. $\mathrm{He}$ is right to distance himself from thinkers such as Hauerwas, who believed that the nation-state is sinful (pp. 21-22), but the fact that states exist and will follow their own interests still poses a problem for the retribution of injustice. In Christianity, Diplomacy and War (1953), Herbert Butterfield points to this problem when he argues that the state and secular humanism had done away with any notion of worldly justice. In the context of Biggar's book, this leads one to ask whether justice can really ever take on true meaning without it in some sense having a universal appeal.

Justice is but one of the factors guiding war. While one can reasonably agree with Biggar that one cannot fully predict the likely consequences of armed intervention, states must consider the fact that the fog cast over one's ability to predict is in itself reason to exercise caution before committing to war. That is, the "unknown unknowns" of any situation should play a critical role in the decision to go to war. States may and do act out of a sense of justice but it is only one part of their overall calculation. Iraq may or may not have had just cause under Biggar's formulation, but those American voices that argued for caution and restraint were thinking about the longer term. We now know that the Iraq war was damaging not just to the US' reputation, but also to its willingness to fight wars in the future. Barack Obama's election to the presidency was partly about ending America's wars, and this has articulated to some degree the public's hesitancy for the US' role as the world's policeman. Paradoxically, intervening in Iraq may have dented America's appetite to fight even greater injustices in the future.

Biggar has written a thought-provoking book that is very timely given the four-year commemoration of the First World War and the ongoing debate about the second Iraq war. He has a forensic eye for detail and argues persuasively, yet, given the emotions that are triggered during any debate on war, this book will, as any good book should, divide opinion.

\section{Conflict of Interests}

The author declares no conflict of interests.

\section{References}

Butterfield, H. (1953). Christianity, diplomacy and war. London: Epworth.

Niebuhr, R. (1940). Christianity and power politics. New York: Scribner's.

Niebuhr, R. (1953). Christian realism and political problems. New York: Scribner's.

Niebuhr, R. (1960). Moral man and immoral society: A study in ethics and politics. New York: Scribner's.

Niebuhr, R. (1979). An interpretation of Christian ethics. New York: Seabury Press.

Tuck, R. (2002). The rights of war and peace: Political thought and the international order from Grotius to Kant. Oxford/New York: Oxford University Press.

\section{About the Author}

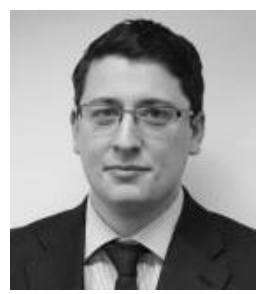

Daniel Fiott

Daniel Fiott is a Researcher at the Institute for European Studies, Vrije Universiteit Brussel, a Fellow of the Research Foundation-Flanders (FWO) and a Senior Editor of European Geostrategy. Daniel's research principally focuses on Europe's defence industries and markets, but he has also published research on military intervention, diplomacy, realist thought, European foreign policy and defence studies. He is the co-editor of a recently published book entitled The Responsibility to Protect and the Third Pillar: Operationalisation and Legitimacy (Palgrave). 